Original article

DOI: http://doi.org/10.20914/2310-1202-2021-2-133-136

\title{
Using local micro-biota to extract biodegradable plastics from food waste through a natural fermentation process
}

\begin{tabular}{|c|c|c|}
\hline & $\begin{array}{ll}\text { Merhawi K. Tsegay } & \mathbf{1} \\
\text { Lyudmila T. Sukhenko } & 1\end{array}$ & $\begin{array}{l}\text { merapg12@gmail.com } \\
\text { sukhenko@list.ru }\end{array}$ \\
\hline \multicolumn{3}{|c|}{ 1 Astrakhan State University, 20a Tatischev Str., Astrakhan, Russia } \\
\hline \multicolumn{3}{|c|}{$\begin{array}{l}\text { Summary. The main problems of mankind in recent decades are the accumulation of various industrial, agricultural, and food produc- } \\
\text { tion wastes. Their ineffective disposal and management practices have a detrimental effect on human health and cause environmental } \\
\text { pollution, which requires urgent action. Food waste has become a complex phenomenon lately, attracting the attention of scientists, } \\
\text { consumers, and activists. This study aims to apply the biotechnology of converting food waste into crystals of polylactic acid (PLA), } \\
\text { a monomer for biodegradable plastic. A food waste sample is taken from the student canteen; wash, to remove impurities and fermen- } \\
\text { tation of carbohydrate waste by autotrophic lactic acid bacteria in a natural process for about seven days in the optimal temperature } \\
\text { range. Finally, lactic acid molecules polymerized by condensation reaction to form poly L-lactic acid (PLA) crystals, and then a bio- } \\
\text { degradable bioplastic. }\end{array}$} \\
\hline
\end{tabular}

\section{Introduction}

Plastics are known to be more useful than many other materials because of their lightness, excellent processability, economy, therefore they are more profitable when choosing materials in many industrial and commercial proposals. In the twentieth century, the production of most traditional plastics from petroleum was widely used [1]. But these petroleum-based plastics are causing serious environmental problems around the world because they are not biodegradable [2]. For this reason, the use of such plastics is prohibited in many countries around the world.

Recently due to shortages petroleum and environmental concerns have intensified the innovation of new cost-effective, greener alternatives [3]. Thus bio-based and biodegradable polymers have emerged as novel alternatives that have the peculiar ability to be ultimately converted into biomass and harmless by-products through the action of microbes [4]. The so-called green polymers can offer sustainable development in the economy and ecology [3], preserving fossil-based raw materials, and minimizing the volume of plastic garbage via decomposition in the natural cycle contributing to climate protection [5].

Food waste implies simply foods intended for consumption but are discarded and cannot be used, and the term 'food losses' mostly refer to the decrease in the amount of food staff throughout the food supply chain which is supposed to be used for human consumption [6]. In many countries in addition to plastic waste, food waste also has become a common occurrence due to lack of storage technologies, out of dates, food prepared for

$$
\text { Для цитирования }
$$

Цегай М.К., Сухенко Л.Т. Использование местной микробиоты для извлечения биоразлагаемого пластика из пищевых отходов путем естественного процесса ферментации // Вестник ВГУИТ. 2021. T 83. № 2. C. 133-136. doi:10.20914/2310-1202-2021-2-133-136

(C) 2021, Цегай М.К. и др. / Tsegay M.K. et al. a group of people in colleges, marriage parties, and other festivals. It has increased even more after the start of the buffet system, period of competition, and ostentation. When food waste is dumped, it decomposes and causes a bad odor to the surrounding, it pollutes water, land, and climate (contributes to increase in greenhouse gas emissions, GHG) as well as biodiversity [7], many times animal deaths or ill are reported due eating the rotting food. Therefore converting food wastes to bio-based organic products such as biogas, bio-fertilizer, or PLA (bioplastic) is a double advantage, because it leads to lowering GHG emissions, minimizing the amount of non-biodegradable plastics, and decreasing the accumulation of food garbage in landfills.

Polylactic acid (PLA), one of the most promising is bio-compatible thermoplastic aliphatic polyester. It is produced by the polymerization of lactides. PLA is used for many different applications, from packaging to agricultural products and disposable materials, as well as, surgery and pharmaceutical fields $[8,9]$. More ever PLA and its copolymers which have been developed as biomedical materials were based on their bio-absorbability and bio-compatibility nature and are been used in many therapeutic and pharmaceutical fields such as drug delivery systems, protein encapsulation, and delivery development of microspheres and hydrogels $[9,10]$.

Lactic acid (2-hydroxy propionic acid) is the basic building block for PLA. It is a highly watersoluble, three-carbon chiral acid that is naturally occurring and is most commonly found in the L (-) isomer form. It has a chemical formula of $\mathrm{CH}_{3} \mathrm{CHOHCOOH}$, and its chemical name is the commonly occurring hydroxycarboxylic acid.

$$
\text { For citation }
$$

Tsegay M.K., Sukhenko L.T. Using local micro-biota to extract biodegradable plastics from food waste through a natural fermentation process. Vestnik VGUIT [Proceedings of VSUET]. 2021. vol. 83 no. 2. pp. 133-136.. doi:10.20914/2310-1202-2021-2-133-136

This is an open access article distributed under the terms of the Creative Commons Attribution 4.0 International License 
It was first discovered in 1780 by the Swedish chemist Scheele [11]. Lactic acid is found naturally as an organic acid and can be produced either by fermentation or chemical synthesis. In the case of fermentation condition, a pure form of lactic acid can be obtained however in chemical production it is a racemic mixture [12]. It is present in many foods both naturally and as a product of in-situ microbial fermentation. The lactic acid bacteria generally include several classes in terms of cell morphology, genus Leuconostoc, Lactococcus, Lactobacillus, Pediococcus, Enterococcus, Streptococcus, Vagococcus, Aerococcus, Carnobacterium, Tetragenococcus, Oenococcus, and Weissell [12, 13], most of them produce L-lactic acid while few produce D or DL-lactic acids. Fermentation can be carried out in batch or continuous type $[14,15]$.<smiles>C[C@H](O)C(=O)O</smiles><smiles>C[C@H](O)C(=O)O</smiles>

\section{L-lactic acid}

D-lactic acid

Figure 1. Three-dimensional structure of $\mathrm{L}(+)$ - lactic acid and $\mathrm{D}(-)$ - lactic acid

\section{Materials and Methods}

Airtight container (3L), muslin cloth, $\mathrm{pH}$ meter, thermometer, electronic balance, measuring cylinders and centrifuge machine, test tubes, Bunsen burner, test tube holder, Petri-dishes, beakers, biuret, conical flask, spatula pipet, refrigerator, inoculation loop, incubation, Sulphuric acid $\left(\mathrm{H}_{2} \mathrm{SO}_{4}\right)$, Calcium hydroxide $\left(\mathrm{Ca}(\mathrm{OH})_{2}\right)$, Methanol, Distilled water, Hydrochloric acid $(\mathrm{HCl})$, chocolate agar media, anti-bumping granules.

Two kilograms of rice waste were collected from the student cafeteria waste collector and washed to remove dirty components such as oil, spices, and others, then it was mixed with two liters of distilled water in a plastic container with a tight cover (figure 2.). Its initial PH was recorded and allowed to be fermented (batch fermentation Process) in an open environment for one week (seven days), within a temperature range of $30-35^{\circ} \mathrm{C}[16]$.

During the fermentation process, the $\mathrm{pH}$ was regularly measured using a $\mathrm{pH}$ meter at $6 \mathrm{pm}$ each day (table 1). When the $\mathrm{pH}$ meter showed constant reading after the fifth day for the next two days, filtration was carried out using a muslin cloth. The solid residue containing the undigested rice dead cells and other impurities were discarded. The broth was then treated with $310 \mathrm{ml}$ Calcium hydroxide (Chem. Rxn 1) and stored at $4^{0} \mathrm{C}$ for
3 days[16]. The solution was poured into test tubes and was centrifuged at $3500 \mathrm{rpm}$ for 15 minutes. The liquid part was discarded from each test tube and the precipitate (solid part) in each test tube was dissolved by Methanol. The solution from each test tube was collected into one large beaker and subsequently, hydrolysis was carried out using $70 \%$ $\mathrm{H}_{2} \mathrm{SO}_{4}$, (chem Rxn 2) to obtain lactic acid (liquid) and calcium sulfate (precipitate) and stored at $4{ }^{\circ} \mathrm{C}$ for 3 days, for more precipitate formation. Thereafter it was distributed in test tubes and then centrifuged at $3000 \mathrm{rpm}$ for 15 minutes to separate the calcium sulfate (solid ppt.) which was discarded), and liquid, (methanol and lactic acid solution) (chem. Rxn 3). The solution was boiled at $100{ }^{\circ} \mathrm{Cremove}$ methanol and water leaving lactic acid alone. Pure lactic acid was collected measured and was tested for its chemical and physical properties, such as $\mathrm{pH}$, boiling point, and concentration. Finally, lactic acid was polymerized to form crystals of polylactic acid crystals (figure 2.) $[17,18]$.

Table 1.

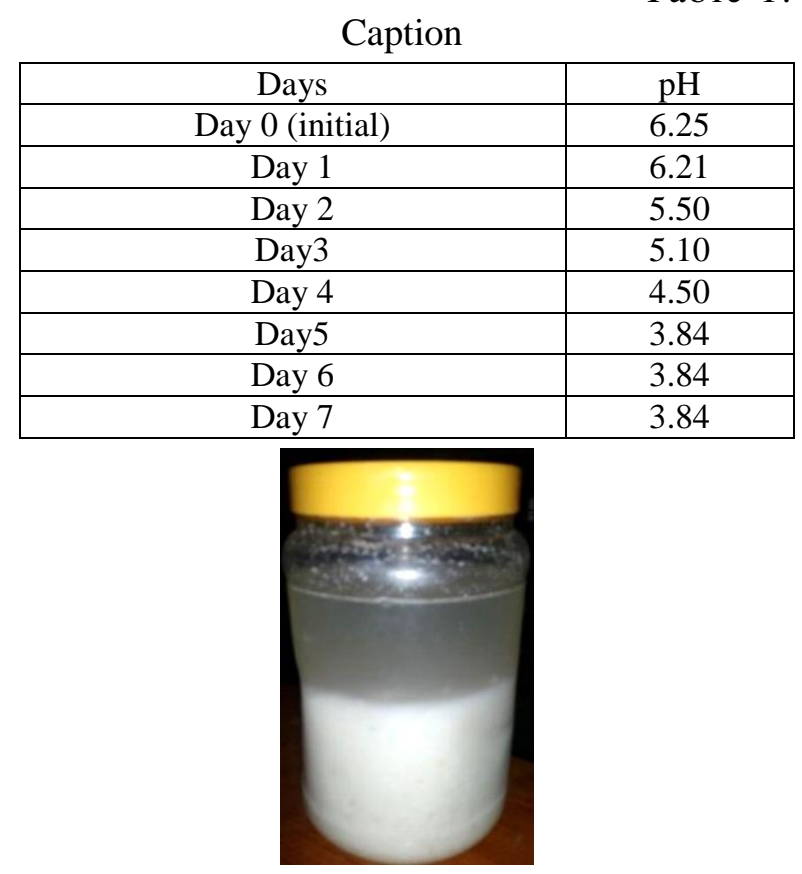

Figure 2. Bio-rector plastic container

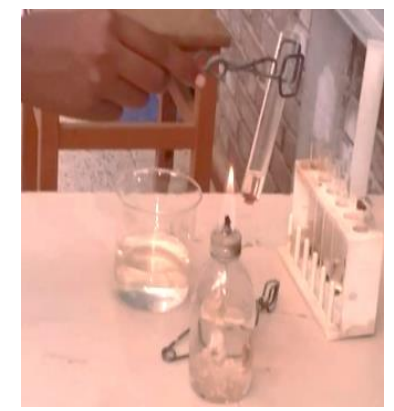

Figure 3. Polymerization of lactic acid 10:58 table 1. PH measures 


\section{Result and discussion}

Lactic acid was the main organic acid produced ( $\approx 98 \%)$ from starchy food waste fermentation by a lactic acid-producing group of bacteria followed by minor impurities such as acetic acid and formic acid and carbon dioxide, provided optimum parameters are maintained $30^{\circ} \mathrm{C}$ to $40^{\circ} \mathrm{C}$ and $\mathrm{pH}$ of 6.0 to 6.5 that promotes the growth of lactic acidproducing bacteria [19]. During the fermentation process, the $\mathrm{pH}$ was dropped from the initial 6.21 to 3.84 , until the fifth day when it came to be constant $(3.84 \mathrm{pH})$ for the next two days (table 1). This gradual drop of $\mathrm{pH}$ was due to the formation of organic acid as a result of the metabolic activity of the microorganisms using the substrate sugar from rice. A similar trend was also obtained by Sakai and Ezaki (2006), whereby lactic acid was the predominant organic acid produced in kitchen waste fermentation. Calcium hydroxide was added gently to 1.51 broth to form calcium lactate precipitate (Chemical reaction 1 ) and simultaneously $\mathrm{pH}$ was measured upon the addition of Calcium hydroxide to obtain the average $\mathrm{pH}$ of calcium lactate around 6 . The solution was stored in a refrigerator at $4^{0} \mathrm{C}$ for three days to get good precipitated [16]

The calcium lactate solution was poured into several test tubes and was centrifuged at $3500 \mathrm{rpm}$ for 15 minutes just to get a good solid precipitate of calcium lactate; this precipitate (solid part) in each test tube was dissolved by Methanol which is known as the esterification process. The addition of $70 \% \mathrm{H}_{2} \mathrm{SO}_{4}$ (hydrolysis) (Chemical reaction 2) lead to the production of lactic acid (liquid) and byproduct calcium sulfate (precipitate) after storage at $4{ }^{\circ} \mathrm{C}$ for 3 days and centrifugation at $3000 \mathrm{rpm}$ for 15 minutes concentrate precipitate was formed.

Chemical reaction $1.2 \mathrm{C}_{2} \mathrm{H}_{5} \mathrm{COOH}+\mathrm{Ca}(\mathrm{OH})_{2} \rightarrow$ $\left(\mathrm{C}_{2} \mathrm{H}_{5} \mathrm{COO}\right)_{2} \mathrm{Ca}+\mathrm{H}_{2} \mathrm{O}$

Chemical reaction 2. $\left(\mathrm{C}_{2} \mathrm{H}_{5} \mathrm{COO}\right)_{2} \mathrm{Ca}+$ $+\mathrm{H}_{2} \mathrm{SO}_{4} \rightarrow 2 \mathrm{CH}_{3} \mathrm{CHOHCOOH}$ (aqua) $+\mathrm{CaSO} 4$

The solution was boiled at $100{ }^{\circ} \mathrm{C}$ to remove methanol (B.pt. $78{ }^{\circ} \mathrm{C}$ ) and water (B.pt. $100{ }^{\circ} \mathrm{C}$ ) leaving lactic acid alone (B. Pt. $122^{\circ} \mathrm{C}$ ). Finally, $256 \mathrm{ml}$ lactic acid is obtained from the two kilograms of rice waste and was polymerized using a condensation reaction (Chemical reaction 3 ) to form polylactic acid crystals[20].

Chemical reaction 3. $2 \mathrm{CH}_{3} \mathrm{CHOHCOOH}_{\rightarrow}$ $\mathrm{C}_{6} \mathrm{H}_{8} \mathrm{O}_{4}+\mathrm{H}_{2} \mathrm{O}$ (polymerization)

There were slight deviations for some of the chemical and physical standard parameters, such as $\mathrm{pH}$, boiling point, and concentration. This fluctuation could be due to substrate characteristics, $\mathrm{pH}$, and temperature fluctuations.

\section{Conclusions}

Kitchen wastes comprise a lot of active indigenous microbes where it plays significant roles in converting large molecules into simpler molecules. In this study, lactic acid fermentation with indigenous bacteria was investigated using batch fermentation with intermittent $\mathrm{pH}$ adjustments to 6 and 8 at ambient temperature 30-35. PLA is being used as raw material for the production of bio-plastics not solely because of its biodegradability but also is made from renewable resources. PLA is in both durable and short-term applications. Increasing demand for lactic acid and research on eco-friendly polylactic acid production has made it necessary to develop a sustainable and conventional method for lactic acid production by fermentation. By now it is obvious that under controlled environmental conditions like at $\mathrm{pH}$ temperature substrate etc. the productivity of lactic acid by fermentation can be increased and thus take this advantage to produce biodegradable plastics all over the planet.

\section{Acknowledgment}

I would like to thank my scientific advisor Sukhenko Lyudmila Timofeevna Doctor of Biological Sciences, Associate Professor in Astrakhan state university for encouraging me to publish this material by editing, commenting and recommending this journal. Furthermore, I would like to thank Alayt Abrhaley, Roda Mhretab, and Yodit Gebreyesus for their valuable contribution, also I would like to thank the lab technicians for their kindness and facilitation and other colleagues for their valuable comments and pieces of advice.

\section{References}

1 Narancic T., Cerrone F., Beagan N., O’Connor K.E. Recent Advances in Bioplastics: Application and Biodegradation. Polymers. 2020. vol. 12. no. 4. pp. 920. doi: 10.3390/polym12040920

2 Sakai K. et al. Selective Proliferation of Lactic Acid Bacteria and Accumulation of Lactic Acid during Open Fermentation of Kitchen Refuse with Intermittent pH Adjustment. Food Sci. Technol. Res. 2000. vol. 6. no. 2. pp. 140-145. doi: 10.3136/fstr.6.140

3 Kwan T.H., Hu Y., Lin C.S.K. Techno-economic analysis of a food waste valorisation process for lactic acid, lactide and poly(lactic acid) production. J. Clean. Prod. 2018. vol. 181. pp. 72-87. doi: 10.1016/j.jclepro.2018.01.179

4 Farah S., Anderson D.G., Langer R. Physical and mechanical properties of PLA, and their functions in widespread applications - A comprehensive review. Adv. Drug Deliv. Rev. 2016. vol. 107. pp. 367-392. doi: 10.1016/j.addr.2016.06.012 
5 Cacciotti I., Mori S., Cherubini V., Nanni F. Eco-sustainable systems based on poly(lactic acid), diatomite and coffee grounds extract for food packaging. Int. J. Biol. Macromol. 2018. vol. 112. pp. 567-575. doi: 10.1016/j.ijbiomac.2018.02.018

6 Ng H.S., Kee P.E., Yim H.S., Chen P.-T. et al. Recent advances on the sustainable approaches for conversion and reutilization of food wastes to valuable bioproducts. Bioresour. Technol. 2020. vol. 302. pp. 122889. doi: 10.1016/j.biortech.2020.122889

7 Newsome T., van Eeden L. The Effects of Food Waste on Wildlife and Humans. Sustainability. 2017. vol. 9. no. 7. pp. 1269. doi: 10.3390/su9071269

8 Garlotta D.A literature review of poly (lactic acid). Journal of Polymers and the Environment. 2001. vol. 9. no. 2. pp. 63-84.

9 Jha A., Kumar A. Biobased technologies for the efficient extraction of biopolymers from waste biomass. Bioprocess Biosyst. Eng. 2019. vol. 42. no. 12. pp. 1893-1901. doi: 10.1007/s00449-019-02199-2

10 Singhvi M.S., Zinjarde S.S., Gokhale D.V. Polylactic acid: synthesis and biomedical applications. J. Appl. Microbiol. 2019. vol. 127. no. 6. pp. 1612-1626. doi: 10.1111/jam.14290

11 Sirisansaneeyakul S., Luangpipat T., Vanichsriratana W., Srinophakun T. et al. Optimization of lactic acid production by immobilized Lactococcus lactis IO-1. J. Ind. Microbiol. Biotechnol. 2007. vol. 34. no. 5. pp. 381-391. doi: 10.1007/s10295-007-0208-6

12 Cubas-Cano E., González-Fernández C., Ballesteros M., Tomás-Pejó E. Biotechnological advances in lactic acid production by lactic acid bacteria: lignocellulose as novel substrate: Lactic acid production from lignocellulose: Biotechnological advances. Biofuels Bioprod. Biorefining. 2018. vol. 12. no. 2. pp. 290-303. doi: 10.1002/bbb.1852

13 Djukić-Vuković A., Mladenović D., Ivanović J., Pejin J. et al. Towards sustainability of lactic acid and poly-lactic acid polymers production. Renew. Sustain. Energy Rev. 2019. vol. 108. pp. 238-252. doi: 10.1016/j.rser.2019.03.050

14 Bayitse R. Lactic Acid Production from Biomass: Prospect for Bioresidue Utilization in Ghana: Technological Review. International Journal of Applied Science and Technology. 2015. vol. 5. no. 1. pp. 12.

15 Eiteman M.A., Ramalingam S. Microbial production of lactic acid. Biotechnol. Lett. 2015. vol. 37. no. 5. pp. 955-972. doi: 10.1007/s10529-015-1769-5

16 Tang J., Wang X., Hu Y., Zhang Y. et al. Lactic acid fermentation from food waste with indigenous microbiota: Effects of pH, temperature and high OLR. Waste Manag. 2016. vol. 52. pp. 278-285. doi: 10.1016/j.wasman.2016.03.034 17 Brigham C.J., Riedel S.L. The Potential of Polyhydroxyalkanoate Production from Food Wastes. Appl. Food Biotechnol. 2019. vol. 6. no. 1. doi: 10.22037/afb.v6i1.22542

18 Choksi N., Desai H. Synthesis of biodegradable polylactic acid polymer by using lactic acid monomer. International Journal of Applied Chemistry. 2017. vol. 13. no. 2. pp. 377-384.

19 Abd Alsaheb R.A. et al. Recent applications of polylactic acid in pharmaceutical and medical industries. J. Chem. Pharm. Res. 2015. vol. 7. pp. 51-63.

20 Komesu A., Maciel M.R.W., Filho R.M. Lactic acid production to purification: a review. BioResources. 2017. vol. 12. no. 2. pp. 4364-4383.

\section{Information about authors}

Merhawi K. Tsegay Ph. D. student, biology faculty, Astrakhan State University, 20a Tatischev Str., Astrakhan, Russia, merapg12@gmail.com

Lyudmila T. Sukhenko Dr. Sci., biology faculty, Astrakhan State University, 20a Tatischev Str., Astrakhan, Russia, sukhenko@list.ru

Contribution
Merhawi K. Tsegay consultation during the study
Lyudmila T. Sukhenko wrote the manuscript, correct it before filing in editing and is responsible for plagiarism

Conflict of interest

The authors declare no conflict of interest.

Received 4.13.2021

Accepted 5.19.2021 